\title{
RODZINA Z PROBLEMEM ALKOHOLOWYM - STUDIUM PRZYPADKU. W KIERUNKU POMOCY I WSPARCIA
}

\begin{abstract}
Streszczenie
Rodzina z problemem alkoholowym określana jest również, jako dysfunkcyjna. Z przegladu dotychczasowego stanu badań wynika, że nie jest ona zdolna wypetniać podstawowych funkcji (opiekuńczej, wychowawczej, socjalizacyjnej, matzeńskiej, ekonomicznej itp.). Oddziałuje w sposób dysfunkcyjny na poszczególnych jej członków, w tym głównie na dzieci, kształtując u nich różne zaburzenia o charakterze internalizujacym oraz lęk i depresję.

Na podstawie wywiadu, przegladu opinii psychologa oraz testu EPQ-R-S-kwestionariusz osobowości Hansa J. Eysenck i Sybila B.G. Eysenck (2006), który postużyt do określenia stopnia uzależnienia od alkoholu rodziców, dokonano analizy funkcjonowania rodziny z problemem alkoholowym, w tym zaburzeń w zachowaniu chłopca. Celem badania byto poznanie stopnia oddziatywania rodziny alkoholowej (niekorzystnych czynników w niej tkwiacych) na zaburzenia w zachowaniu chłopca. $Z$ analizy materialu wynika, że rodzina z problemem alkoholowym, stanowi nie najlepsze środowisko dla rozwoju, życia i funkcjonowania chłopca. Nie gwarantuje ona prawidtowej opieki $i$ wychowania, co implikuje nasilaniem się u niego wielu zaburzeń w zachowaniu, w tym pojawianie się zamiast „rodzenie się” myśli samobójczych. Cała rodzina wymaga pomocy specjalistycznej oraz wsparcia osób najbliższych. Propozycje i formy pomocy zostaty opisane w części końcowej tekstu.
\end{abstract}

Słowa kluczowe: rodzina, problem alkoholowy, pomoc, wsparcie

* Malgorzata Przybysz-Zaremba - dr hab., prof. UKSW, Katedra Pedagogiki Rodziny, Wydział Studiów Nad Rodziną, Uniwersytet Kardynała Stefana Wyszyńskiego w Warszawie. 


\section{Rodzina z problemem alkoholowym - tytułem wprowadzenia}

Rodzinę z problemem alkoholowym charakteryzuje chaos, dezorganizacja, niestabilność emocjonalna, wysoki poziom konfliktu, trudne relacje małżeńsko-rodzinne, zmniejszenie spójności oraz zwiększenie izolacji społecznej. W literaturze jest ona określana jako rodzina dysfunkcyjna, która nie spełnia swoich zadań. Zdaniem Marii Ryś ${ }^{2}$ do najważniejszych z nich należą: zabezpieczenie przetrwania i rozwoju swoich członków, zaspokojenie podstawowych potrzeb, w tym potrzeb emocjonalno-psychicznych, dbanie o równowagę pomiędzy autonomią a zależnością oraz edukacja w zakresie zachowań społecznych, która jest niezwykle ważna w rozwoju i kształtowaniu osobowości i poczucia własnego ,ja”. Tymczasem, jak wskazuje wiele badań w rodzinie z problemem alkoholowym podstawowe funkcje (rodzicielska, małżeńska, socjalizacyjna, opiekuńcza, ekonomiczna itp.) są zaniedbywane. Główne miejsce w rodzinie zajmuje alkohol, który staje się problemem całej rodziny. Dotychczasowy stan badań, w tym zakresie jest bardzo bogaty. Ukazuje wielość a także złożoność negatywnych skutków doświadczanych przez członków w rodzinie alkoholowej. Najbardziej niebezpieczne są skutki dla rozwoju i funkcjonowania dzieci. Oprócz wczesnego i łatwego dostępu do alkoholu, dzieci doświadczają wielu różnych problemów i zaburzeń emocjonalno-psychicznego samopoczucia, które często manifestują w swoim zachowaniu. Alexandra Loukas, Hiram E. Fitzgerald, Robert A. Zucker oraz Jennifer L. Krull ${ }^{3}$ poddali analizie trajektorię od okresu przedszkolnego do wczesnego dojrzewania problemów u 302 chłopców z zaburzeniami zachowania w wieku od przedszkola do wczesnego dojrzewania. Badani rekrutowali się z rodzin wysokiego ryzyka ${ }^{4}$. $Z$ badań wynika, że podwyższony poziom zaburzeń w zachowaniu chłopców „,mocno” związany był z problem alkoholowym rodziców. Panujące w rodzinie konflikty, oddziaływały na

1 K. A. Polak, L. I. Puttler, M. A. Ilgen, The Relationship between Structural Aspects of Self-Concept and Psychosocial Adjustment in Adolescents from Alcoholic Families, „Substance Use \& Misuse” 2012, No. 5, Vol. 47 Issue 7, p. 827-836.

2 M. Ryś, Role petnione w rodzinie z problemem alkoholowym a poczucie własnej wartości i relacje interpersonalne z najbliższymi u Dorostych Dzieci Alkoholików, Kwartalnik Naukowy „Fides et Ratio” 2011, 4(8), s. 94.

A. Loukas, H. E. Fitzgerald, R. A. Zucker, J. L. Krull, Developmental Trajectories of Disruptive Behavior Problems Among Sons of Alcoholics: Effects of Parent Psychopathology, Family Conflict, and Child Undercontrol, ,Journal of Abnormal Psychology” 2003, No. 2, Vol. 112, Issue 1, p. 119.

4 W rodzinach badanych chłopców występował problem alkoholowy u jednego z członków. 
wzrost zaburzeń w zachowaniu chłopców, szczególnie w okresie wkraczania w kolejny etap edukacji. Badacze wskazują, że wzrost ten wynika z antyspołecznych zaburzeń osobowości rodziców nadużywających alkoholu, którzy zaniedbywali wychowawczo swoje dzieci. Nie sprawowali kontroli nad ich zachowaniem, zakłócającym przejście z jednego poziomu edukacji na drugi (przejście z przedszkola do szkoły), co skutkowało nasileniem się zaburzeń w zachowaniu.

U dzieci wychowywanych w rodzinie alkoholowej obserwuje się również podwyższony poziom objawów internalizujących ${ }^{5}$, w tym lęku i depresji. Badania przeprowadzone przez U. W. Preussa, M. A. Schuckita, T. L. Smitha, S. Barnow i G. P. Danko ${ }^{6}$ wskazują, że poziom tych objawów (szczególnie zaburzenia nastroju i lęku) wzrasta wraz ze wzrostem liczby osób w rodzinie (krewnych) nadużywających alkoholu. Zaburzenia te, niejednokrotnie są na tyle „głębokie”, że mogą utrzymywać się przez wiele lat, a niekiedy i przez całe życie. $Z$ badań przeprowadzonych przez Marie C. Haverfield oraz Jennifer A. Theiss ${ }^{7}$ wśród 622 dorosłych dzieci alkoholików (DDA) wynika, że osoby wychowywane w rodzinie alkoholowej dotknięte są stygmatyzacją. Doświadczają dyskryminacji, zaburzeń depresyjnych, niskiego poczucia własnej wartości i niskiej odporności na doznawany stres. Rzadko wracają do tematów rodzinnych dotyczących problemu alkoholowego. Zdaniem T. Mackrilla i M. Hessea ${ }^{8}$, dzieci rodziców nadużywających alkoholu znajdują się w grupie ryzyka, które skłania się w kierunku zarówno sięgania po alkohol, jak i podejmowania prób samobójczych ${ }^{9}$. Tak więc piętno alkoholizmu

5 Do objawów internalizujących zalicza się zaburzenia związane z emocjami, takie jak: smutek, przygnębienie, lęk, wycofanie się z kontaktów z innymi. Zob. U. W. Preuss, M. A. Schuckit, T. L. Smith, S. Barnow, G. P. Danko, Mood and anxiety symptoms among 140 children from alcoholic and control families, „Drug \& Alcohol Dependence” 2002, No. 8, Vol. 67, Issue 3, p. 235.

6 U. W. Preuss, M. A. Schuckit, T. L. Smith, S. Barnow, G. P. Danko, tamże.

7 M. C. Haverfield, J. A. Theiss, Parent's alcoholism severity and family topic avoidance about alcohol as predictors of perceived stigma among adult children of alcoholics: Implications for emotional and psychological resilience, „Health Communication” 2016, No. 5, Vol. 31, Issue 5, p. 606-616.

8 T. Mackrilla, M. Hessea, Suicide behavior in parents with alcohol abuse problems and suicide behavior in their

Offspring - Adult offspring and counselor perspectives, „Nordic Journal of Psychiatry” 2012, No. 10, Vol. 66, p. 343-348.

9 Badacze wskazują, że rodzice nadużywający alkoholu podejmują również próby samobójcze. T. Mackrilla, M. Hessea, tamże. Z kolei badania przeprowadzone przez A. L. Głowińskiego i współpracowników na grupie 143 rodziców uzależnionych od alkoholu, wskazują, że 46,1\% osób zgłaszało zachowania samobójcze. A. L. Głowiński, 
rodziców, może uniemożliwić dzieciom rozwiązywanie problemów i radzenie sobie $\mathrm{z}$ ich otoczeniem.

Celem tekstu jest analiza rodziny z problemem alkoholowym, jako studium przypadku. W rodzinie objętej badaniem występuje problem alkoholowy obojga rodziców, który prowadzi do wszelkich zaniedbań opiekuńczo-wychowawczych względem chłopca i zaburzeń w jego zachowaniu. Na podstawie przeprowadzonych wywiadów z poszczególnymi członkami rodziny (wywiady zostały przeprowadzone $z$ obojgiem rodziców, synem i córką), opinii psychologa oraz testu EPQ-R-S - kwestionariusz osobowości Hansa J. Eysenck i Sybila B. G. Eysenck (2006), który posłużył do określenia stopnia uzależnienia od alkoholu ${ }^{10}$ dokonano analizy życia i funkcjonowania rodziny (przede wszystkim syna) z problemem alkoholowym. Głównym celem badania, było poznanie czynników dysfunkcyjnych tkwiących w rodzinie i ich oddziaływania na zaburzenia w zachowaniu chłopca. Materiał pozyskany został przez studentó $\mathrm{w}^{11} \mathrm{~W}$ ramach przedmiotu diagnostyka w profilaktyce społecznej i resocjalizacji. Wszelkie dane personalne dotyczące badanej rodziny (ich imiona i nazwisko) zostały zmienione.

\section{Rodzina z problemem alkoholowym - studium przypadku}

\section{Ogólna deskrypcja rodziny Nowaków objętych badaniem}

Rodzina Państwa Nowaków składa (ła) się z pięciu osób: Ela, lat 52, Wojtek, lat 53 oraz trójka dzieci: Magda, lat 30, Jacek - w wieku 19 lat popełnił samobójstwo oraz Robert, lat 14.

Ela Nowak - wykształcenie zawodowe. Wiele lat pracowała w zawodzie wyuczonym, jako krawcowa, jednak z powodu problemu alkoholowego została zwolniona z pracy. Aktualnie pracuje w Domu Pomocy Społecznej w Rawie Mazowieckiej, w charakterze opiekuna osób starszych. Praca wykonywana jest w systemie zmianowym. Miesięczny dochód kształtuje się na poziomie około 1500 zł. Z powodu

K. K. Bucholz, E. C. Nelson, Q. Fu, P. A. F. Madden, W. Reich, et al., Suicide attempts in an adolescent female twin sample, „J Am Acad Child Adolesc Psychiatry” 2001, No. 40, p. 1300-1307.

10 Dokumenty zostały udostępnione przez poradnię, której klientami są małżonkowie Nowak.

11 Annę Lach i Paulinę Zarembę. 
problemów zdrowotnych a także powrotu do nałogu alkoholowego ${ }^{12}$, od kilku miesięcy przebywa na zwolnieniu lekarskim. $Z$ powodu obaw związanych z utratą pracy, kobieta boi się podjąć leczenia odwykowego. W środowisku lokalnym, nie bywa widywana pod wpływem alkoholu, a w okresie abstynencji utrzymywała dobre kontakty z sąsiadami. Obecnie izoluje się od sąsiadów. Wielokrotnie wysuwa obietnice synowi (Robert), że „kończy z piciem alkoholu”, ale już po tygodniu ponownie sięga po alkohol. Kobieta wymaga pomocy specjalistycznej i leczenia odwykowego.

Wojtek Nowak - wykształcenie zawodowe (wyuczony zawód - masarz). Kilkakrotnie zmieniał zakłady pracy. Przez urząd pracy został skierowany na staż do pracy w prywatnym magazynie, na stanowisko pracownika gospodarczego. Pracuje w godz. 7.00-15.00. Jego wynagrodzenie miesięczne wynosi około $1200 \mathrm{zł}$. Okres trzeźwości wynosił 6 lat. Obecnie Pan Wojtek, podobnie jak żona, powrócił do nałogu. Alkohol spożywał sporadycznie (raz w tygodniu) przed popełnieniem samobójstwa przez syna Jacka, który jak stwierdził ,,był moim oczkiem w głowie”. Pan Wojtek miał bardzo dobry kontakt z synem. Z perspektywy czasu dostrzega zaburzenia i nieprawidłowości w funkcjonowaniu jego rodziny a przede wszystkim w wypełnianiu na rzecz dzieci obowiązków rodzicielskich.

Magda - wykształcenie średnie. Wyuczony zawód - technik żywienia. Obecnie mieszka w Łodzi. Pracuje jako doradca ds. klienta. Jej wynagrodzenie za pracę wynosi nieco ponad 2700 zł. W roku 2011 zawarła związek małżeński. Mąż Arkadiusz Kalisz, posiada wykształcenie wyższe I stopnia w zakresie zarządzania zasobami ludzkimi. Jego dochód miesięczny kształtuje się na poziomie najniższej krajowej.

Robert, uczeń drugiej klasy Gimnazjum w Rawie Mazowieckiej. Chłopiec wielokrotnie uciekał z domu, nie uczęszczał na zajęcia lekcyjne, znacznie opuścił się w nauce szkolnej, jest agresywny, miewa myśli samobójcze. Obecnie przebywa u siostry Magdy w Łodzi.

Państwo Nowakowie mieszkają w wielorodzinnym murowanym domu. Zajmują lokal mieszkalny składający się z dwóch pokoi i kuchni. Mieszkanie posiada podstawowe udogodnienia w postaci wody bieżącej, łazienki i centralnego ogrzewania. Pomieszczenia wyposażone są w niezbędny sprzęt i meble, utrzymane we względnej czystości.

Syn Robert ma do swojej dyspozycji oddzielny pokój wyposażony stosownie do jego wieku, między innymi w biurko do odrabiania lekcji, komputer.

Państwo Nowakowie nie utrzymują kontaktów z najbliższą rodziną. Pan Wojtek posiada brata, z którym spotyka się dwa razy w roku, głównie podczas świąt.

12 Kobieta w przeszłości miała problem z nadużywaniem alkoholu. Przez kilkanaście lat utrzymywała abstynencję, jednak obecnie powróciła do nałogu. 
Rodzice nie żyją. Pani Ela, ma brata, siostrę oraz matkę, którzy mieszkają w tej samej miejscowości. Ojciec nie żyje. Rodzina Pani Eli jest pozytywnie postrzegana w środowisku lokalnym, bez patologii i uzależnień, cieszy się dobrą opinią. W przeszłości siostra pani Eli występowała z wnioskiem o wszczęcie procedury, podczas której małżonkowie Nowak zostali poddani leczeniu odwykowemu. Niestety nie udało się im zachować abstynencję - powrócili do nałogu.

Kilka informacji na temat przebiegu prowadzenia wywiadu

„Do mieszkania państwa Nowaków udało się dostać dopiero po długotrwałym i energicznym pukaniu w okna. Użycie dzwonka oraz pukanie do drzwi nie skutkowało. Podczas wizyty w miejscu zamieszkania, obydwoje rodzice byli pod wpływem alkoholu. Trudno było z nimi nawiązać do końca prawidłowy kontakt słowny. Pani Ela „,zachowywała się płaczliwie”. Udzielane przez nią informacje przeplatane były „płaczem, szlochami”. Pan Wojciech, chwilami był wielomówny przerywał stawiane pytania, niekiedy tracił wątek swoich wypowiedzi. Powtarzał po kilka razy, te same wypowiedzi. Rozmowa wymagała ciągłego nakierowywania i dopytywania. Zdaniem p. Nowaków w domu nie ma awantur. Oboje rodziców przebieg pożycia małżeńskiego i relacje w rodzinie - postrzegają i określają, jako poprawne"13.

Problem alkoholowy w rodzinie jako główne podłoże kształtowania się zaburzeń w zachowaniu chłopca

U obojga małżonków zdiagnozowano chorobę alkoholową, której stan można określić jako krytyczny ${ }^{14}$. Jest to stadium choroby, które charakteryzuje się (w zależności od indywidualnych predyspozycji organizmu, intensywności picia oraz rodzaju spożywanego alkoholu - stadium to może trwać kilka miesięcy) stałą utratą kontroli nad przebiegiem picia alkoholu, którego potrzeba spożywania staje się koniecznością fizyczną i psychiczną. Nieodzowność picia alkoholu jest tak silna, że osoby uzależnione od niego, aby w miarę dobrze funkcjonować (mam tu na myśli

13 Fragment relacji i odczuć przedstawionych przez studentki.

14 Szerzej na temat charakterystyki choroby alkoholowej patrz: M. Przybysz-Zaremba, Terapia profesjonalna i samopomocowa w uzależnieniu alkoholowym, Wydawnictwo Enea Communication, Toruń 2006, J. Mellibruda, Tajemnice ETOH, PARPA, Warszawa 1993, J. Mellibruda, Psycho-bio-społeczna koncepcja uzależnienia od Alkoholu, „Alkoholizm i Narkomania" 1997, nr 3. 
wykonywać podstawowe czynności domowe, a nawet ,być zdolnym do pracy”15) muszą niezależnie od pory dnia, dostarczyć alkohol do organizmu. Zachowania takie, zaobserwowano u p. Nowaków podczas prowadzenia z nimi wywiadu. Z dokumentacji udostępnionej przez poradnię wynika, że oboje małżonkowie wymagają systemowego i specjalistycznego leczenia. Niestety z różnych względów, nie decydują się na podjęcie leczenia, nawet w sytuacji śmierci jednego z synów, który popełnił samobójstwo a drugi (Robert) zmierza w podobnym kierunku. Zdaniem małżonków ,picie alkoholu to jeszcze nie problem, ponieważ wich domu nie ma awantur”. Tymczasem, najmłodszy syn Robert nie radzi sobie z atmosferą, jaka panuje w domu. Podczas prowadzenia z nim wywiadu stwierdził:

„[...] od jakiegoś czasu, przed snem, zanim usnę do glowy przychodza mi myśli o tym, co Jacek zrobit, ... ale te myśli same przychodza do głowy. Ja je odganiam, ale czasami nawet jak myśle o czymś innym, to one sa, nie wiem czemu te myśli przychodza do mojej głowy [...]”'16.

Robert wielokrotnie opuszczał dom, nie mówiąc nikomu gdzie idzie. Rodzice nie interesowali się jego zniknięciem. Jedynie ciocia (siostra matki), która mieszka $\mathrm{w}$ tej samej miejscowości, podejmowała działania i interesowała się sprawami Roberta. Z jej relacji wynika, że:
„[...] należało włożyć wiele pracy, przeprowadzić wiele rozmów, aby wypracować u Roberta obowiazek informowania jej, gdzie przebywa, co zamierza".

Robert z kolei wskazywał, że ,rodzice nie interesuja się jego osoba a więc nie widziat potrzeby informowania kogokolwiek o swoich zamiarach". Zaczął wykorzystywać obecną sytuację. Zdarzały się nieobecności na zajęciach lekcyjnych, pogorszyły się oceny w szkole. Gdy problemy zaczęły narastać, w ich rozwiązywanie włączyła się siostra Magda, która wspierała ciocię w działaniach, a z czasem przejęła całkowitą opiekę nad bratem. Od 25 sierpnia 2016r. Robert przebywa u siostry w Łodzi, która stworzyła jemu warunki do nauki (chłopiec ma swój pokój, wyposażony w kanapę, biurko, szafę, komputer, telewizor). Codziennie

15 „Być zdolnym do pracy” - określenia tego używam na podstawie relacji osób uzależnionych od alkoholu, którzy twierdzą, że „wypicie jednego klina” pomaga im normalnie funkcjonować.

16 Cytat w sposób dosłowny przedstawia wypowiedź chłopca. 
z Łodzi dojeżdża do Rawy Mazowieckiej do szkoły. Koszty utrzymania i dojazdu do szkoły ponosi siostra $\mathrm{z}$ mężem.

$\mathrm{Z}$ analizy dokumentacji udostępnionej przez poradnię oraz $\mathrm{z}$ wywiadu przeprowadzonego z Magdą wynika, że Robert jest chłopcem „,mocno” zaniedbanym wychowawczo, z potencjałem, który jest „marnowany” i niedostrzegany przez rodziców alkoholików. Robert interesuje się gastronomią, szczególnie pieczeniem ciast i w przyszłości chciałby zdobyć zawód cukiernika oraz w tym kierunku pracować. Lubi słuchać muzyki, śpiewać, majsterkować, wędkować oraz uprawiać sport (siatkówkę). W sytuacjach kryzysowych, do których dochodziło w domu, głównie gdy rodzice znajdowali się pod wpływem alkoholu - szukał pomocy, wsparcia a przede wszystkim zrozumienia u siostry Magdy, do której jeździł w weekendy, gdzie otrzymywał satysfakcjonującą opiekę, pomoc i wsparcie. Czas z siostrą i jej mężem, spędzał na długich rozmowach, które dotyczyły najczęściej indywidualnych problemów chłopca i sytuacji, z jaką ma do czynienia $\mathrm{w}$ domu rodzinnym, wspólnym graniu w gry edukacyjne (głównie planszowe), wspólnym czytaniu książek, wychodzeniu na miasto. Robert zawsze mógł liczyć na pomoc siostry, przy odrabiania pracy domowej. I zawsze - jak podkreślił - „na brak zaufania wobec deklaracji rodziców”. Wielokrotnie bowiem, doznał rozczarowania wobec złożonych przez rodziców obietnic i zobowiązań. Nie chce doświadczać sytuacji braku poczucia bezpieczeństwa i deprywacji jego potrzeb. Chłopiec jest już zmęczony atmosferą, jaka panuje w domu. „Nie znosi widoku zapitej twarzy matki i ojca"17, którzy wielokrotnie obiecywali, że zaprzestaną picia alkoholu. Tymczasem, w domu zawsze, gdy rodzice byli pod wpływem alkoholu dochodziło do krzyków i awantur. Chłopiec nie mógł skupić się na zajęciach a prace domowe często chodził odrabiać do kolegów z klasy. Nie ma zaufania do rodziców, którzy wielokrotnie go zawiedli - wstydzi się ich. Pragnie zmienić środowisko zamieszkania oraz szkołę. Jak stwierdził:
„[...] do domu rodzinnego wrócę tylko w przypadku, gdy rodzice przejda leczenie przeciwalkoholowe i będa utrzymywać abstynencję. Mam świadomość, że alkoholikiem jest się przez całe życie, ale do- świadczytem już życia z alkoholikami w abstynencji. Lęk pozostaje, ale gdy nie pili byto dobrze".

Rodzice chłopca nie wykazują zainteresowania podtrzymywaniem kontaktów z synem. Nie podejmują żadnych działań w kierunku poprawy swojej sytuacji życiowej, zmiany postawy rodzicielskiej a przede wszystkim podjęcia leczenia. Deklarują silny związek emocjonalny z synem, tymczasem nie podejmują żadnych kroków w tym kierunku.

17 Cytat w sposób dosłowny przedstawia wypowiedź chłopca. 
Robert obecnie przebywa u siostry Magdy w Łodzi, która wraz z mężem podejmuje starania stworzenia chłopcu rodziny zastępczej. Siostra wraz z mężem mieszka w mieszkaniu o powierzchni $82 \mathrm{~m} . \mathrm{kw}$. W skład mieszkania wchodzą trzy pokoje, kuchnia, łazienka. Mieszkanie wyposażone jest w instalację wodno-kanalizacyjną i elektryczną, ogrzewane jest piecami węglowymi. Woda podgrzewana jest przy użyciu bojlera elektrycznego. Mieszkanie wyposażone jest w podstawowy sprzęt i nie posiada zadłużeń. Magda wraz z mężem od maja 2015r. podjęli starania stworzenia chłopcu rodziny zastępczej. Początkowo, próbowała wpływać na rodziców, aby to oni podjęli leczenie i stworzyli „prawdziwą" rodzinę chłopcu, jednak w przypadku tych działań relacje pomiędzy nimi zaczęły się pogarszać. Rodzice nie wykazywali większego zainteresowania się chłopcem. Matka, czasami dzwoniła do Roberta, gdy przebywał u siostry, ojciec natomiast nie wykazywał żadnego zainteresowania. Robert podejmował próby kontaktu telefonicznego z rodzicami, niestety gdy telefon był odbierany przez matkę, z rozmowy wskazywało, że była ona w stanie nietrzeźwym. Takie sytuacje miały miejsce rzadko, jednak gdy do nich dochodziło, chłopiec wpadał w ,histerię”, krzyczał, płakał - przez dłuższy czas nie był w stanie normalnie funkcjonować. $Z$ relacji siostry wynika, że chłopiec zgłaszał myśli samobójcze:

\section{„[...] Janek - brat, który odebrat sobie życie - dobrze zrobił, bo rozwiazat wszystkie swoje problemy".}

Siostra wraz z mężem podejmuje działania na rzecz pomocy bratu. Cała trójka uczęszcza na terapię, która jest jednym z ważnych elementów w sprawowaniu opieki nad nieletnim. Decyzję o stworzeniu rodziny zastępczej bratu, Magda i jej mąż uzasadniają bliską relacją uczuciową z chłopcem oraz chęcią zapewnienia jemu właściwych warunków do prawidłowego rozwoju emocjonalnego i społecznego. Pragną zapewnić Robertowi stabilne środowisko rodzinne, a przede wszystkim poczucie bezpieczeństwa i możliwości realizowania obowiązku szkolnego w Łodzi. Deklarują chłopcu, wsparcie w realizacji jego zainteresowań i uzdolnień. Są zatroskani o jego stan zdrowia.

Z analizy dokumentacji wynika, że państwo Kalisz kwalifikują się na zostanie rodziną zastępczą dla Roberta. Nigdy nie byli pozbawieni praw rodzicielskich, nie są ograniczeni ani zawieszeni w ich wykonywaniu oraz nie ciąży na nich obowiązek alimentacyjny z tytułu egzekucyjnego, nie są ograniczeni w zdolności do czynności prawnych oraz nie cierpią na schorzenie, które stanowi przeciwskazanie do pełnienia funkcji rodziny zastępczej. Nie są osobami uzależnionymi od alkoholu i środków psychoaktywnych. Nie znajdują się w kartotece krajowego rejestru karnego. Posiadają bardzo dobrą opinię w zakładach pracy. 
Pomoc i wsparcie rodziny z problemem alkoholowym - propozycje i zalecenia

Z przedstawionego materiału wynika, że rodzina z problemem alkoholowym stanowi niekorzystne środowisko opiekuńczo-wychowawcze. W rodzinie z problemem alkoholowym (szczególnie, gdy problem dotyczy obojga rodziców) istnieje wiele czynników kształtujących (wyzwalających) zaburzenia w zachowaniu nieletnich. Jednym z najbardziej niebezpiecznych, dezorganizujących funkcjonowanie całego systemu rodziny jest problem alkoholowy, którego oddziaływanie często wyzwala inne faktory, jak np. zaniedbania opiekuńczo-wychowawcze, brak prawidłowych wzorców, agresja, przemoc, brak czasu dla dziecka - prowadzenia z nim rozmów oraz niski status społeczno-ekonomiczny rodziny. Są to główne determinanty występujące w badanej rodzinie, które kształtują zaburzenia w zachowaniu chłopca. Również traumatyczne doświadczenia związane z samobójstwem brata, kształtowały u Roberta myśli samobójcze. To tragiczne wydarzenie rodzinne, być może wpłynęło także na nieudolność oraz brak siły i wiary w podjęciu leczenia odwykowego przez państwa Nowaków, a co za tym idzie braku zainteresowania się synem Robertem.

Cała rodzina wymaga pomocy i wsparcia w powrocie do ,,normalnego” funkcjonowania, które powinno mieć wymiar zarówno indywidualny, jak i systemowy. I tak, małżonkowie Nowak potrzebują pomocy w zakresie:

- intensyfikacji motywacji do podjęcia stacjonarnego leczenia odwykowego, które jest podstawą sprawnego funkcjonowania rodziny;

- leczenia odwykowego, którego wymiar będzie miał charakter zarówno indywidualny (detoksykacja, farmakoterapia, psychoterapia), jak i grupowy (terapia długoterminowa, udział w mitingach grup AA);

- udziału Roberta i Magdy w terapii rodzinnej, której celem jest wsparcie rodziców w utrzymywaniu trzeźwości;

- podjęcia edukacji, której podstawą jest nabycie umiejętności w zakresie radzenia sobie z problemami dnia codziennego;

- udziału w terapii (np. humanistyczno-podtrzymującej, interpretacyjnej, behawioralnej, adlerowskiej itp. ${ }^{18}$, mającej na celu minimalizowanie bądź całkowite likwidowanie doświadczanych kryzysów, konfliktów w sferze relacji z bliskimi. Budowanie i podtrzymywanie sprawnych relacji małżeńskich, rodzicielskich.

18 Szerzej na temat rodzajów terapii piszą: Colin Feltham, Ian Horton, Psychoterapia i poradnictwo, tom 1, GWP, Sopot 2013, Harold S. Bernard, K. R. MacKenzi (red.), Podstawy terapii grupowej, GWP, Gdańsk 2001. 
Pomoc Robertowi powinna mieć charakter holistyczny. Zaleca się w tym przypadku:

- wykorzystanie czynników chroniących ściśle związanych z chłopcem oraz $\mathrm{z}$ jego otoczeniem, tj. środowiskiem (rodzinnym), w którym przebywa. Niewątpliwie ważnym czynnikiem chroniącym są indywidualne zasoby Roberta, jego zainteresowania, które należy rozwijać, pielęgnować i kultywować. Aby stały się one podstawą w odnalezieniu siebie i swojego miejsca w życiu;

- $\quad$ w przypadków czynników chroniących stricte związanych ze środowiskiem (rodzinnym) wychowawczym chłopca, należy ograniczyć - szczególnie na czas trwania postępowania - władzę rodzicielską rodzicom Roberta (Eli i Wojtkowi Nowak), poprzez umieszczenie go w rodzinie zastępczej ustanowionej w osobie Magdy i Arkadiusza Kalisz ${ }^{19}$;

- udział Roberta i jego rodziców zastępczych (Magdy i Arkadiusza) w terapii mającej na celu budowanie dobrych relacji;

- zapewnienie chłopcu możliwości korzystania ze stałej konsultacji psychiatry dziecięcego oraz wsparcia psychologicznego;

- udział szkoły w pomocy i wsparciu Roberta w napotykanych problemach edukacyjnych a także w rozwijaniu jego zainteresowań;

- kształtowanie umiejętności w zakresie rozwiązywania problemów i konfliktów bez agresji i przemocy, szukania pomocy.

\section{Wnioski i implikacje dla praktyki}

Praca z rodziną z problemem alkoholowym wymaga wielu wysiłków i starań wszystkich członków rodziny, ich chęci i udziału w wydobywaniu i konstruowaniu zasobów (potencjału) poszczególnych osób w rodzinie, które stanowią niewątpliwie bardzo ważne podłoże w pomocy specjalistycznej. Na zasoby i potencjał ten, składają się m.in. kompetencje społeczne (umiejętności interpersonalne, asertywność, umiejętność radzenia sobie w sytuacjach trudnych, współpraca w grupie, umiejętność rozwiązywania problemów, porozumiewanie się); kompetencje motywacyjne (umiejętność stawiania sobie celów i dążenie do ich osiągania); umiejętności poznawcze (zdolność do koncentracji uwagi, rozwój wyobraźni); pozytywna samoocena (świadomość swoich mocnych stron oraz zdolność do ich wykorzystywania); samoświadomość (zdolność do rozpoznawania i wyrażania swoich emocji); samokontrola (zdolność do powstrzymywania negatywnych reakcji) oraz rozwój

19 Procedura ustanowienia Magdy i Arkadiusza Kalisz rodziną zastępczą dla nieletniego Roberta jest w trakcie realizacji. 
duchowy (praktyki religijne i duchowe) ${ }^{20}$. Kompetencje te, (obok pomocy stricte specjalistycznej związanej bezpośrednio z uzależnieniem od alkoholu i współuzależnieniem) powinny stanowić główny trzon działań pomocowo-wspierających rodzinę. I tak, w zakresie kompetencji społecznych zaleca się m.in.:

- udział w zajęciach i warsztatach, mających na celu kształtowanie świadomości zapewnienia optymalnego poziomu zdrowia fizycznego i psychicznego, czyli jaki obrać styl życia, który przyczyni się do tego?;

- kształtowanie umiejętności zasad postępowania i reguł zachowania przyjętych w różnych społecznościach, np. w zakładzie pracy. Umiejętności te, przyczynią się do poprawienia kontaktów interpersonalnych i aktywnego uczestnictwa w życiu społecznym;

- kształtowanie umiejętności w zakresie konstruktywnego porozumiewania się w różnych środowiskach, wykazywania tolerancji, negocjowania, tworzenia klimatu zaufania oraz zdolności do empatii ${ }^{21}$;

- kształtowanie umiejętności w zakresie radzenia sobie ze stresem, frustracją, wyrażaniem emocji, w tym $\mathrm{z}$ agresją.

W kształtowaniu kompetencji motywacyjnych zaleca się działania uwzględniające zarówno motywację zewnętrzną, jak i wewnętrzną. Jednym z najważniejszych wymiarów jest jednak uświadomienie jednostce celu, do którego dąży, jako priorytetu do osiągnięcia w określonym czasie. Martin Ford w opracowanej teorii motywacji, zwrócił uwagę na następujące cele, które są bardzo istotne w rodzinie z problemem alkoholowym. Autor wskazuje na cele: „emocjonalne (np. spokój, zadowolenie), poznawcze (np. zaspokajanie ciekawości, dochodzenie do wiedzy o czymś), subiektywnej harmonii (np. doświadczanie uczucia harmonii, doznawanie uczucia doskonałego funkcjonowania), integracji poprzez stosunki społeczne (np. wypełnianie społecznych zobowiązań, działanie na rzecz uczciwości, udzielanie poparcia społecznego) oraz zadaniowe (np. sprawna i skuteczna realizacja codziennych zadań)"22. W zakresie tych celów należy prowadzić pomocowo-wspierające. Ponadto, jednostce uzależnionej od alkoholu należy ukazać korzyści,

20 M. Przybysz-Zaremba, Rodzina a zachowania ryzykowne młodzieży, w: Rodina, tolerancia inakosti a kvalita života detí a mládeže, red. Zlatica Bakošová, Vydala Univerzita Komenského v Bratislave vo Vydavatel'stve UK, Bratislava 2017, s. 37.

21 B. Kubiczek, Projekt ,,Szkoła Demokracji-Szkoła Samorzadności”. Kompetencje społeczne i obywatelskie uczniów i nauczycieli, Ośrodek Rozwoju Edukacji, Sosnowieckie Centrum Edukacyjne „EDUKATOR”, Sosnowiec 2012, s. 2-3.

22 Podaję za: M. Cywińska, Rozwijanie motywacji uczniów do nauki, „Studia Edukacyjne” 2012, nr 20, s. 153-166. 
jakie dotychczas czerpała z życia przed nadużywaniem (uzależnieniem) alkoholu. W tym zakresie, należy:

- uzmysłowić osobiste zainteresowania, indywidualne potrzeby oraz możliwości doskonalenia się i rozwoju - bez alkoholu;

- stwarzać sytuacje doświadczania sukcesu i samodzielnego pokonywania problemów i porażek;

- włączyć domowników rodziny w pomoc i wsparcie osoby uzależnionej w osiąganiu wyznaczonego celu, uwzględniając zewnętrzne czynniki wzmacniająco-motywacyjne.

W planowaniu pomocy osobie uzależnionej i jej rodzinie ważne jest, aby obierane działania miały charakter procesu, który oprócz nakreślonych powyżej kompetencji społeczno-motywacyjnych uwzględniał będzie, także działania zmierzające do kształtowania samoświadomości i samokontroli oraz podnoszenia samooceny. Ważne jest także utrwalanie nabytych umiejętności i kompetencji oraz wzmacnianie duchowe poprzez kultywowanie praktyk religijnych.

Zaproponowane (wybrane) propozycje, wymagają zaangażowania specjalistów, tj. pedagogów, psychologów, terapeutów i psychoterapeutów, duchownych oraz osób bezpośrednio współpracujących z osobami uzależnionymi i współuzależnionymi. Bez ich pomocy, aktywności i oddania, rodzina z problemem alkoholowym nie jest w stanie „powrócić do życia” i ,normalnie” funkcjonować w środowisku społecznym.

\section{Malgorzata Przybysz-Zaremba: Family with alcohol problem - a case study. Towards assistance and support}

\section{Summary}

Family with alcohol problem is also defined as a dysfunctional family. The review of the current research shows that such a family is not able to fulfil the basic functions (of the following types: care, educational, social, marital, economic and the others.) It interacts dysfunctionally with its particular members, especially children, forming in them various disorders of internalising character and also fear and depression. On the basis of an interview, a psychologist's opinion review and the test EPQ-R-S - the personality questionnaire by Hans J. Eysenck $i$ Sybil $B$. G. Eysenck (2006), which was used to define the level of parents' alcohol addiction, an analysis of family functioning with the alcohol problem was performed, including the disorders of a boy's behaviour. The purpose was to learn the degree of the alcohol family's interaction (the unfavourable factors rooted there) with the disorders in the boy's behaviour. The analysis of the material shows that a family 
with alcohol problem is not the best environment for the boy's development, life and functioning. Such a family guarantees neither the proper care nor education, which triggers the increase of the in behavioural disorders, including the ,foundation of" suicidal thoughts. The whole family is in need of some specialist support and the assistance for the closest relatives. The offers and forms of such support are presented in the final part of the text.

Key words: family, alcohol problem, support, assistance

\section{Bibliografia}

Bernard Harold S., MacKenzi K. R. red., Podstawy terapii grupowej, GWP, Gdańsk 2001.

Cywińska M., Rozwijanie motywacji uczniów do nauki, „Studia Edukacyjne” 2012, nr 20.

Feltham C., Horton I., Psychoterapia i poradnictwo, tom 1, GWP, Sopot 2013.

Głowiński A. L., Bucholz K. K., Nelson E. C., Fu Q., Madden P. A. F., Reich W., et al., Suicide attempts in an adolescent female twin sample, „J Am Acad Child Adolesc Psychiatry" 2001, No. 40, p. 1300-1307.

Haverfield M. C., Theiss J. A., Parent's alcoholism severity and family topic avoidance about alcohol as predictors of perceived stigma among adult children of alcoholics: Implications for emotional and psychological resilience, „Health Communication" 2016, No. 5, Vol. 31, Issue 5, p. 606-616.

Kubiczek B., Projekt „,Szkoła Demokracji-Szkoła Samorzadności”. Kompetencje społeczne i obywatelskie uczniów i nauczycieli, Ośrodek Rozwoju Edukacji, Sosnowieckie Centrum Edukacyjne „EDUKATOR”, Sosnowiec 2012, s. 2-3.

Loukas A., Fitzgerald H. E., Zucker R. A., Krull J. L., Developmental Trajectories of Disruptive Behavior Problems Among Sons of Alcoholics: Effects of Parent Psychopathology, Family Conflict, and Child Undercontrol, „Journal of Abnormal Psychology" 2003, No. 2, Vol. 112, Issue 1, p. 119.

Mackrilla T., Hessea M., Suicide behavior in parents with alcohol abuse problems and suicide behavior in their Offspring - Adult offspring and counselor perspectives, „Nordic Journal of Psychiatry” 2012, No. 10, Vol. 66, p. 343-348. Mellibruda J., Tajemnice ETOH, PARPA, Warszawa 1993.

Mellibruda J., Psycho-bio-społeczna koncepcja uzależnienia od Alkoholu, „Alkoholizm i Narkomania” 1997, nr 3.

Polak K. A., Puttler L. I., Ilgen M. A., The Relationship between Structural Aspects of Self-Concept and Psychosocial Adjustment in Adolescents from Alcoholic Families, „Substance Use \& Misuse” 2012, No. 5, Vol. 47 Issue 7, p. 827-836. 
Preuss U. W., Schuckit M. A., Smith T. L., Barnow S., Danko G. P., Mood and anxiety symptoms among 140 children from alcoholic and control families, „Drug \& Alcohol Dependence” 2002, No. 8, Vol. 67, Issue 3, p. 235.

Przybysz-Zaremba M., Rodzina a zachowania ryzykowne młodzieży, w: Rodina, tolerancia inakosti a kvalita života detí a mládeže, red. Zlatica Bakošová, Vydala Univerzita Komenského v Bratislave vo Vydavatel'stve UK, Bratislava 2017.

Przybysz-Zaremba M., Terapia profesjonalna i samopomocowa $w$ uzależnieniu alkoholowym, Wydawnictwo Enea Communication, Torun 2006.

Ryś M., Role petnione $w$ rodzinie z problemem alkoholowym a poczucie własnej wartości i relacje interpersonalne z najbliższymi u Dorosłych Dzieci Alkoholików, Kwartalnik Naukowy „Fides et Ratio” 2011, 4(8), s. 94. 